InOedia $\quad \begin{aligned} & \text { InMedia } \\ & \text { The French Journal of Media Studies }\end{aligned}$

$2 \mid 2012$

Performing/Representing Male Bonds

\title{
Carol MacKeogh, Díóg O'Connell, Documentary in a Changing State: Ireland since the 1990 s
}

Cork: Cork University Press, 2012, 176 p.

\section{Estelle Epinoux}

\section{(2) OpenEdition}

\section{Journals}

Electronic version

URL: http://journals.openedition.org/inmedia/475

DOI: $10.4000 /$ inmedia.475

ISSN: 2259-4728

Publisher

Center for Research on the English-Speaking World (CREW)

\section{Electronic reference}

Estelle Epinoux, « Carol MacKeogh, Dióg O'Connell, Documentary in a Changing State: Ireland since the 1990s », InMedia [Online], 2 | 2012, Online since 19 December 2012, connection on 24 September 2020 URL : http://journals.openedition.org/inmedia/475 ; DOI : https://doi.org/10.4000/inmedia.475

This text was automatically generated on 24 September 2020

(c) InMedia 


\section{Carol MacKeogh, Díóg O’Connell, Documentary in a Changing State: Ireland since the 1990s}

Cork: Cork University Press, 2012, 176 p.

\section{Estelle Epinoux}

1 Documentary in a Changing State, Ireland since the 1990s, written by two Irish lecturers in media studies, not only falls into the field of media studies but more globally into those of sociology, history, politics and cultural studies with which several links are drawn. It emerged after a documentary conference held in 2007 at the Institute of Art, Design and Technology, at Dún Laoghaire in Ireland. The book is a collection of essays and interviews from different contributors - coming from Northern Ireland, the Republic of Ireland and France - and from different backgrounds: academics (Harvey O'Brien, Desmond Bell), filmmakers (Alan Gilsenan, Donald Taylor Black), producers (Maíre Kearney, Rachel Lysaght), journalists (Mary Raftery) and writers (Kevin Rafter, Alan Gilsenan). It is divided into four sections within which documentaries are looked at from different angles. Both the producing context the documentaries were made in and the impact of those films are analysed.

2 The first section deals with theory and practice, starting a reflection on the role of documentary, then exploring ethnographic and socially engaged documentaries and ending with a study on the relationship of history to documentary film, referring to documentaries such as Hard Road to Klondike (1999) or Rebel Frontier (2004), both directed by Desmond Bell.

3 The second section of the book entitled "Documentary: Critical Practice" includes personal reflections from practitioners who, in the past twenty years, have addressed social issues in documentaries which have had an impact on Irish society and which also highlight "the ethical dilemmas that the documentary maker must face" (p. 10) when directing a documentary.

4 The third section of the book tackles the questions of policy and politics regarding documentaries, presenting different aspects of production. It starts with the main 
changes which have taken place in documentary production. It then pinpoints the roles of independent producers and directors as well as the role of RTÉ (Raidió Teilifís Éireann) in financing documentaries. The third section also deals with the question of programming documentaries, referring to the role of TG4 (Teilifís na Gaeilge) - a branch of public service broadcasting - and finishes with the digital impact on documentary in Ireland.

5 The final section of the book relates to the future developments of documentaries in Ireland relying on several interviews with 'key players', according to the authors: the director Ken Wardrop (Love is like a Butterfly, 2004), the producer Alan Maher and the director Mary Raftery (Suffer the Little Children, 1999). The different sections of the book also provide the reader with five tables, which give figures concerning the different financing programmes which have helped to produce documentaries be it by RTÉ or the IPU (Independent Production Unit) as well as figures on the number of hours devoted to documentary programming.

6 Documentary in a Changing State, Ireland since the 1990s offers an interesting insight in the recent developments of documentary films in Ireland and more precisely on their questioning of the Irish State, of Irish history and of current problems, while following its main thread of thought, which is to "explore the ongoing discourse and relationship between theory and practice" (p. 9). The documentary film Unheard Voices (2009) directed by Jolene Mairs and Cahal McLaughlin is an example of that process. Unheard Voices tells the story of six individuals who either lost someone or were injured during the Troubles in Northern Ireland (1968-early 1990s) and in the chapter entitled Unheard Voices: Recording Stories from the Troubles, the directors of the film explain how they conceived their documentary so as "to establish a model of documentary film-making that would allow them to tell their story" (p. 29).

7 The book also provides a historical approach of the evolution of documentaries in Ireland which, fifty years ago, were considered as the "handmaiden of the state" (p. 1) and regarded with suspicion and distrust by the Irish state which resorted to the use of much censorship whereas today the media have become the "watchdog of society" ( $\mathrm{p}$. 1). The reasons for the late flourishing of investigative documentaries in Ireland is thoroughly discussed in the book, which explains that such an evolution has to be found in the "new culture and civil society" (p. 3) which developed in the 1990s and which led to more questioning of Irish society and to less trust in the institutions on the part of the population. It also finds its roots in several changes such as the economic growth undergone by the country, the cultural impact of the Internet on society and Ireland's membership of Europe. The book stresses that the media not only focused on these changes but that they also furthered them. The investigative documentaries made in the 1990s question the evolution of Irish society at large and at the same time they also highlight "the changing state of documentary as a form of communication" (p. 8), describing Irish broadcasting structures and the characteristics of documentary form, documentary appearing as "a prism through which key moments in recent Irish history are negotiated, revealed (...) informing us on the nature of these changes" (p. 11).

8 An example of such an evolution is the documentary Dear Daughter (1996), directed by Louis Lentin, which deals with the story of a woman who spent thirteen years in an industrial school in Dublin, run by the Sisters of Mercy. The impact of the documentary was so important that it "obliged the government to respond to abuses of power in 
religious and state-run institutions" (p. 1). As pointed out in the book, Irish documentaries "have shaken the country's central institutions" (p. xvii). Regarding his documentary, Louis Lentin states that he detests the term 'documentarist', explaining that his role is the following one: "when permitted I tell stories, stories that I hope will reveal, reflect and resonate" (p. 76).

Documentary in a Changing State, Ireland since the 1990s, while providing an in-depth and relevant "insider perspective" (p. 9) of the recent documentaries produced in Ireland also offers an insight into the Irish state and above all it examines the evolution of Irish documentary films in the past twenty years thus filling the gap of an "insufficient recognition of the Irish documentary story" (p. xviii).

\section{AUTHORS}

\section{ESTELLE EPINOUX}

Université de Limoges 